\title{
ANTAGONISTIC POTENTIALITY OF SOME SOIL FUNGI AGAINST SIX FUNGAL PATHOGENS ISOLATED FROM COTTON (GOSSYPIUM HIRSUTUM L.) SEEDS
}

\author{
AMINA KHATUN, SHAMIM SHAMSI* AND ABUL BASHAR \\ Mycology and Plant Pathology Laboratory, Department of Botany, \\ University of Dhaka, Dhaka-1000, Bangladesh
}

\begin{abstract}
The antagonistic potentials of four soil filamentous fungi viz., Aspergillus flavus Link, A. fumigatus Fresenius, A. niger van Tieghem and Trichoderma viride Pers. against six pathogens isolated from 14 varieties of cotton (Gossypium hirsutum L.) were evaluated by "dual culture colony interaction", volatile and non-volatile metabolites. In dual culture colony interaction, out of four soil fungi, T. viride was found be the most effective to control the growth of the cotton pathogens. T. viride showed the highest growth inhibition against Curvularia lunata, Fusarium moniliforme, Mucor sp. and Rhizoctonia solani. On the other hand A. niger showed the highest growth inhibition against Fusarium nivale and $A$. fumigatus showed the maximum growth inhibition against $C$. gloeosporioides. The highest inhibition of radial growth of $C$. lunata, F. nivale and $F$. moniliforme was observed might be due to the secretion of volatile metabolites of $T$. viride whereas, the maximum inhibition of radial growth of $C$. gloeosporioides was observed because of the volatile metabolites of A. flavus. Mucor sp. and R. solani were inhibited due to the volatile metabolites of $A$. fumigatus. The greatest radial growth inhibition of $C$. lunata and $F$. moniliforme were noticed in case of $T$. viride owing to the effect of non-volatile metabolites. On the other hand, the radial growth of $C$. gloeosporioides and $F$. nivale were inhibited highest amount for the effect of non-volatile metabolites of $A$. niger, whereas highest growth inhibition of Mucor $\mathrm{sp}$. and $R$. solani was observed due to the non-volatile effect of $A$. fumigatus. The present investigation suggests that the isolates of Aspergillus and Trichoderma may be further exploited as potential biocontrol agents against the fungal pathogens of cotton in field trial.
\end{abstract}

Key words: Antagonistic potentiality, Fungal antagonists, Cotton pathogens.

\section{Introduction}

Cotton is the most renowned, reliable fiber yielding crops as well as cash crops around the world including Bangladesh. It is the major textile fiber used by man in the world and playing a key role in the economic and social welfare (Munro 1994).

*Corresponding author: <prof.shamsi@gmail.com>. 
Each year, cotton production is being reduced due to the presence of some harmful fungal pathogens. Majority of cotton diseases are seed-borne viz., Alternaria blight, bacterial blight, Fusarium wilt, Myrothecium blight, Cercospora blight, Exserohilum blight etc. A number of seed-borne fungal pathogens such as Alternaria, Fusarium, Rhizopus and Aspergillus are frequently identified in cotton seeds (Minton and Garber 1983). Aspergillus flavus, A. niger (Type-I), Curvularia lunata, Fusarium moniliforme var. subglutinans, F. sporotrichioides and Rhizoctonia solani were found to be pathogenic for Gossypium arboreum in Bangladesh (Naznin and Shamsi 2018).

Application of antagonists to soil and seeds increased seed germination percentage and reduced the seed borne infection. Study of antagonist as biological control agent has now become one of the most exciting and rapidly developing areas in plant pathology, because it has great potential to solve many agricultural and environmental problems. So, there is a need to screen newly available seed dressing molecules including bioagents and botanicals for their efficacy in overcoming the seed-borne infections of fungi.

In Bangladesh, research on biological control of seed-borne fungi of cotton seeds through soil antagonists is very limited. So, for the sake of economy, more information on this regard is essential. Considering the importance of this valuable fiber, present investigation was undertaken to screen out the efficacy of antagonistic fungi against the fungal pathogens associated with cotton seeds.

\section{Materials and Methods}

Collection of samples: Seed samples of CB1-14 were collected from Cotton Research, Training and Seed multiplication Farm, Gazipur after harvesting and were kept in clean glass jars, labeled properly and preserved at room temperature for subsequent use. The experiment was conducted in the Mycology and Plant Pathology Laboratory, Department of Botany, University of Dhaka.

Isolation and identification of fungi: The fungi were isolated from the collected seed samples following the "Tissue Planting Method" on PDA medium (CAB 1968), "Blotter method" and "Paper Towel Method" (ISTA 1996). Morphological identification of the isolates were determined following the standard literatures (Thom and Rapper 1945, Rapper and Thom 1949, Subramanian 1971, Barnett and Hunter 1972, Benoit and Mathur 1970, Booth 1971, Ellis 1971, 1976, Sutton 1980) and molecular identification were done following Amer et al. 2011 with some modifications.

Antagonostic potentiality of fungi: Six pathogenic fungi, namely, Colletotrichum gloeosporioides, Curvularia lunata, Fusarium nivale, F. moniliforme, Mucor sp. and 
Rhizoctonia solani, isolated from 14 varieties of cotton seeds were selected as test pathogens against four antagonistic soil fungi.

Antagonistic fungi were isolated from rhizosphere soil of the host varieties following serial dilution method. Among the isolated fungi, Aspergillus flavus, A. fumigatus, A.

niger and Trichoderma viride were selected to test their antagonistic potentials against the pathogens following "dual culture technique" described by Bashar and Rai (1994). The parameter used for the assessment of the colony interaction and per cent inhibition of radial growth was calculated by the formula of Fokkema (1976). Effects of volatile and non-volatile metabolites of the selected soil fungi against the test pathogens were also studied following the methods described by Bashar and Rai (1994).

Analysis of data: Data were evaluated by analysis of variance (ANOVA) by using STAR statistical program and means were compared using Duncan's Multiple Range Test (DMRT).

\section{Results and Discussion}

Six fungal pathogens viz., Colletotrichum gloeosporioides, Curvularia lunata, Fusarium nivale, F. moniliforme, Mucor sp. and Rhizoctonia solani were isolated from the seeds of 14 varieties of cotton seeds, which were found as virulent in the test of pathogenicity.

In colony interactions, antagonistic relationships among the soil fungi and test pathogens were grade 2 and 4 . However, grade 2 was found to be the most commonly encountered type of colony interaction as 17 interactions were incorporated in this grade, which was followed by grade 4 (Table 1 ).

The intermingled zone between the soil fungi and test pathogens was very common. The maximum intermingled zone $(0.3 \mathrm{~cm})$ was observed in case of A. fumigatus and $T$. viride against Mucor sp. and $R$. solani. T. viride grew over the colony of the test pathogens but in case of A. flavus, A. fumigatus and A. niger inhibition zone was found and it was $0.2,0.2$ and 0.1 , respectively.

All the tested soil fungi inhibited the growth of all the test pathogens to varied degrees in dual culture experiments on PDA plates. A. fumigatus showed the highest inhibition on radial growth of $C$. gloeosporioides $(84.0 \%)$ followed by A. niger (80.0\%), A. flavus (73.9\%) and T. viride (63.1\%). T. viride showed the highest $(76.4 \%)$ growth inhibition on Curvularia lunata which was followed by A. niger (72.2\%), A. fumigatus (68.4\%) and A. flavus (59.0\%). T. viride showed the highest growth inhibition on $F$. moniliforme (73.7\%), which was followed by A.flavus (67.6\%), A. niger (60.0\%) and A. fumigatus 
(53.8\%). A. niger showed the highest growth inhibition $(72.27 \%)$ on $F$. nivale, which was followed by A. flavus (68.1\%), T. viride (66.6\%) and A. fumigatus (45.4\%). $T$. viride showed the maximum growth inhibition on Mucor sp. (60.0\%) which was followed by A. niger (52.1\%) A. flavus (50.0\%), and A. fumigatus (44.1\%). T. viride also showed the highest growth inhibition on Rhizoctonia solani $(46.8 \%)$ which was followed by A. niger (30.2\%) A. flavus (26.6\%), and A. fumigatus (19.3\%) (Table 1 and Fig. 1).

Table 1. Effects of dual culture between fungal antagonists and cotton pathogens.

\begin{tabular}{|c|c|c|c|c|c|}
\hline \multirow[t]{2}{*}{ Test pathogens } & & \multicolumn{4}{|c|}{$\begin{array}{l}\% \text { inhibition of radial growth, intermingled and inhibition zone } \\
\text { and type of reactions of the test pathogens }\end{array}$} \\
\hline & & Aspergillus flavus & A. fumigatus & A. niger & $\begin{array}{l}\text { Trichoderma } \\
\text { viride }\end{array}$ \\
\hline \multirow{4}{*}{$\begin{array}{l}\text { Colletotrichum } \\
\text { gloeosporioides }\end{array}$} & $\%$ inhibition & 73.9 & 84.0 & 80.0 & 63.1 \\
\hline & $\mathrm{IMZ}(\mathrm{cm})$ & 0.1 & 0.2 & 0.2 & 0.1 \\
\hline & $\mathrm{IHZ}(\mathrm{cm})$ & - & - & - & - \\
\hline & Grade & 2 & 2 & 2 & 2 \\
\hline \multirow{4}{*}{$\begin{array}{l}\text { Curvularia } \\
\text { lunata }\end{array}$} & $\%$ inhibition & 59.0 & 68.4 & 72.2 & 76.4 \\
\hline & $\mathrm{IMZ}(\mathrm{cm})$ & - & - & - & 0.2 \\
\hline & $\mathrm{IHZ}(\mathrm{cm})$ & 0.2 & 0.2 & 0.1 & - \\
\hline & Grade & 4 & 4 & 4 & 2 \\
\hline \multirow{4}{*}{$\begin{array}{l}\text { Fusarium } \\
\text { moniliforme }\end{array}$} & $\%$ inhibition & 67.6 & 53.8 & 60.0 & 73.7 \\
\hline & $\mathrm{IMZ}(\mathrm{cm})$ & - & - & - & 0.2 \\
\hline & $\mathrm{IHZ}(\mathrm{cm})$ & 0.1 & 0.2 & 0.2 & - \\
\hline & Grade & 4 & 4 & 4 & 2 \\
\hline \multirow[t]{4}{*}{ Fusarium nivale } & $\%$ inhibition & 68.1 & 45.4 & 72.2 & 66.6 \\
\hline & $\mathrm{IMZ}(\mathrm{cm})$ & 0.2 & 0.1 & 0.1 & 0.1 \\
\hline & $\mathrm{IHZ}(\mathrm{cm})$ & - & - & - & - \\
\hline & Grade & 2 & 2 & 2 & 2 \\
\hline \multirow[t]{4}{*}{ Mucor sp. } & $\%$ inhibition & 50.0 & 44.1 & 52.1 & 60.0 \\
\hline & $\mathrm{IMZ}(\mathrm{cm})$ & 0.2 & 0.3 & - & 0.3 \\
\hline & $\mathrm{IHZ}(\mathrm{cm})$ & - & - & 0.1 & - \\
\hline & Grade & 2 & 2 & 4 & 2 \\
\hline \multirow{4}{*}{$\begin{array}{l}\text { Rhizoctonia } \\
\text { solani }\end{array}$} & $\%$ inhibition & 26.6 & 19.3 & 30.2 & 46.8 \\
\hline & $\mathrm{IMZ}(\mathrm{cm})$ & 0.2 & 0.3 & 0.2 & 0.3 \\
\hline & $\mathrm{IHZ}(\mathrm{cm})$ & - & - & - & - \\
\hline & Grade & 2 & 2 & 2 & 2 \\
\hline
\end{tabular}

$\mathrm{IMZ}=$ Intermingling zone, IHZ = Inhibition zone, and '-' = not applicable. 
Similar observation was also noticed in the study of Akter et al. 2014, Bashar and Chakma 2014, Helal and Shamsi 2019 where A. flavus, A. fumigatus, A. niger and T. viride showed significant growth inhibition against Colletotrichum spp., Curvularia lunata and Fusarium spp.

In dual culture technique, maximum growth inhibition was recorded for Trichoderma spp. against different pathogenic fungi in the research of Tapwal et al. 2015, Patel and Joshi 2001, Sunitha and Kurundkar 2007, Al-Ameen et al. 2017, Goswami and Islam 2002.

Grade 2 = Mutual intermingling growth where the growth of the fungus is ceased and being over growth by the opposed fungus. Grade $4=$ Slight inhibition of both the interacting fungi with narrow demarcation line $(1-2 \mathrm{~mm})$ based on Skidmore and Dickinson (1976).
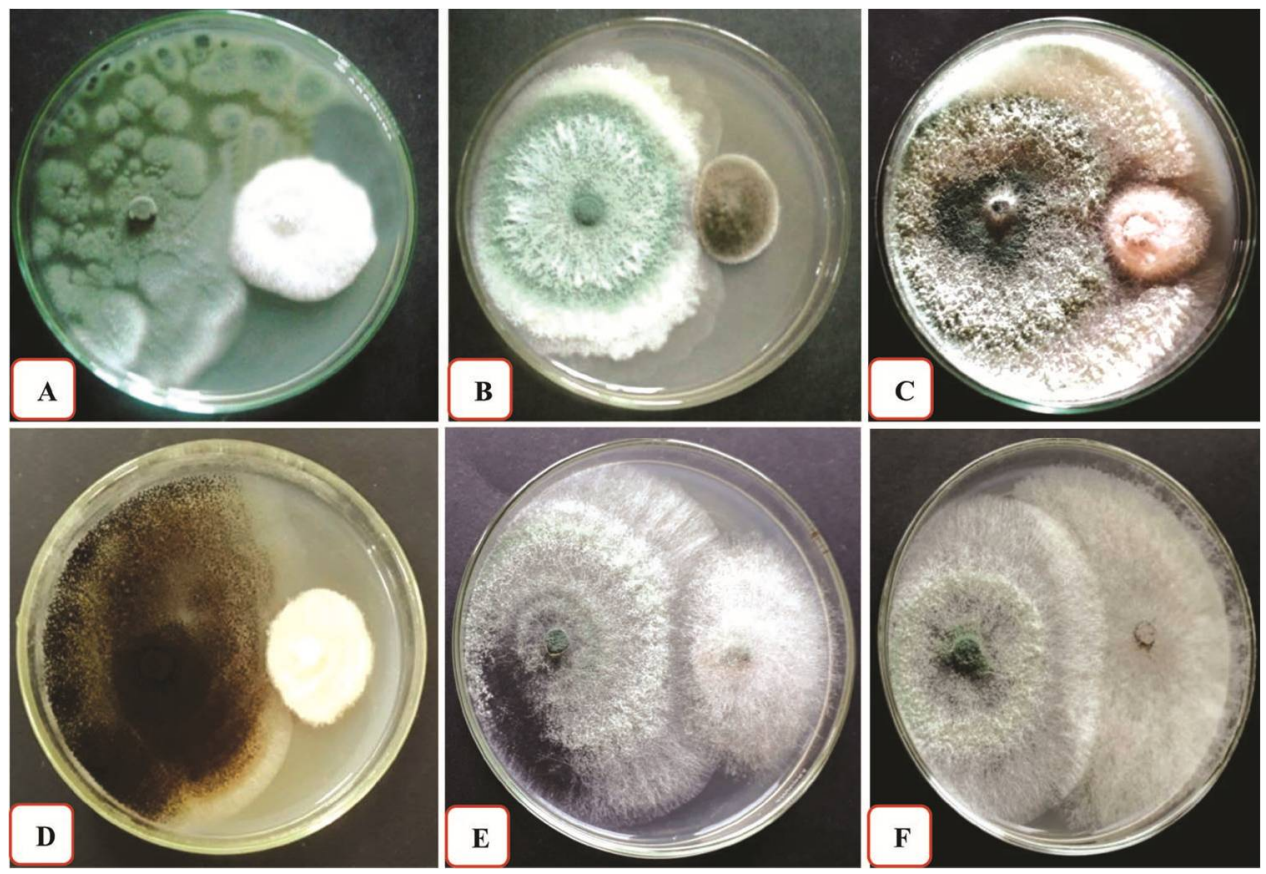

Fig. 1. Photographs showing colony interactions between pathogenic fungi and antagonists. A. Colletotrichum gloeosporioides and Aspergillus fumigatus; B. Curvularia lunata and Trichoderma viride; C. Fusarium moniliforme and T. viride; D. Fusarium nivale and Aspergillus niger; E. Mucor sp. and T. viride; F. Rhizoctonia solani and T. viride. 
The effect of volatile metabolites of antagonistic fungi against cotton seed pathogens are presented in Table 2. The maximum inhibition of radial growth of $C$. gloeosporioides was observed in A. flavus (59\%), which was followed by A. niger (48.7\%), A. fumigatus (38.2\%) and $T$. viride $(35.9 \%)$ due to the volatile metabolites. The maximum inhibition of radial growth of Curvularia lunata was observed in T. viride (71.4\%) followed by $A$. fumigatus (47.6\%), A. flavus (38.1\%) and A. niger (33.3\%) owing to volatile metabolites. The maximum inhibition of radial growth of Fusarium nivale was also observed in T. viride (64.2\%), which was followed by A. niger (54.7\%), A. fumigatus (47.6\%) and A. flavus (40.4\%). Highest inhibition of radial growth of $F$. moniliforme was found by $T$. viride (51.1\%) followed by A. fumigatus (42.2\%), A. niger (40.0\%) and A. flavus (35.5\%). Whereas, A. fumigatus showed 58.2\% inhibition of radial growth of Mucor sp. which was followed by T. viride (55.5\%), A. flavus (47.2\%) and A. niger (36.3\%). At last, maximum inhibition of radial growth of Rhizoctonia solani was noticed in A. fumigatus (72.4\%), which was followed by T. viride (55.5\%), A. niger (53.3\%) and A. flavus (52.2\%) (Table 2 and Fig. 2).

Table 2. Percent inhibition of radial growth of the test pathogens owing to volatile metabolites of antagonistic fungi.

\begin{tabular}{lcccccc}
\hline Antagonistic & \multicolumn{5}{c}{ \% inhibition of radial growth of the test pathogens } \\
\cline { 2 - 7 } fungi & $\begin{array}{l}\text { Colletotrichum } \\
\text { gloeosporioides }\end{array}$ & $\begin{array}{c}\text { Curvularia } \\
\text { lunata }\end{array}$ & $\begin{array}{c}\text { Fusarium } \\
\text { nivale }\end{array}$ & $\begin{array}{c}\text { Fusarium } \\
\text { moniliforme }\end{array}$ & $\begin{array}{c}\text { Mucor } \\
\text { sp. }\end{array}$ & $\begin{array}{c}\text { Rhizoctonia } \\
\text { solani }\end{array}$ \\
\hline $\begin{array}{l}\text { Aspergillus } \\
\text { flavus }\end{array}$ & $58.9^{\mathrm{a}}$ & $38.1^{\mathrm{c}}$ & $40.4^{\mathrm{d}}$ & $35.5^{\mathrm{d}}$ & $47.2^{\mathrm{c}}$ & $52.2^{\mathrm{d}}$ \\
$\begin{array}{l}\text { A. fumigatus } \\
\text { A. niger }\end{array}$ & $38.4^{\mathrm{c}}$ & $47.6^{\mathrm{b}}$ & $47.6^{\mathrm{c}}$ & $42.2^{\mathrm{b}}$ & $58.1^{\mathrm{a}}$ & $72.4^{\mathrm{a}}$ \\
$\begin{array}{l}\text { Trichoderma } \\
\text { viride }\end{array}$ & $48.7^{\mathrm{b}}$ & $33.3^{\mathrm{d}}$ & $54.7^{\mathrm{b}}$ & $40.0^{\mathrm{c}}$ & $36.3^{\mathrm{d}}$ & $53.3^{\mathrm{c}}$ \\
CV\% & $35.9^{\mathrm{d}}$ & $71.4^{\mathrm{a}}$ & $64.2^{\mathrm{a}}$ & $51.1^{\mathrm{a}}$ & $55.5^{\mathrm{b}}$ & $55.5^{\mathrm{b}}$ \\
\hline
\end{tabular}

Means followed by the same letter within a column did not differ significantly at $5 \%$ level by DMRT.

Similar observation was also noticed in the study of Aktar et al. 2014, Bashar and Chakma 2014, Helal and Shamsi 2019, where A. flavus, A. fumigatus, A. niger and T. viride showed significant growth inhibition against Colletotrichum spp., Curvularia lunata and Fusarium spp. 
Al-Ameen et al. (2017) reported that some volatile metabolites released from $T$. viride cultures might be responsible for extending the inhibitory activity against some pathogens such as Colletotrichum and Fusarium species isolated from banana (Musa sepientum L.)
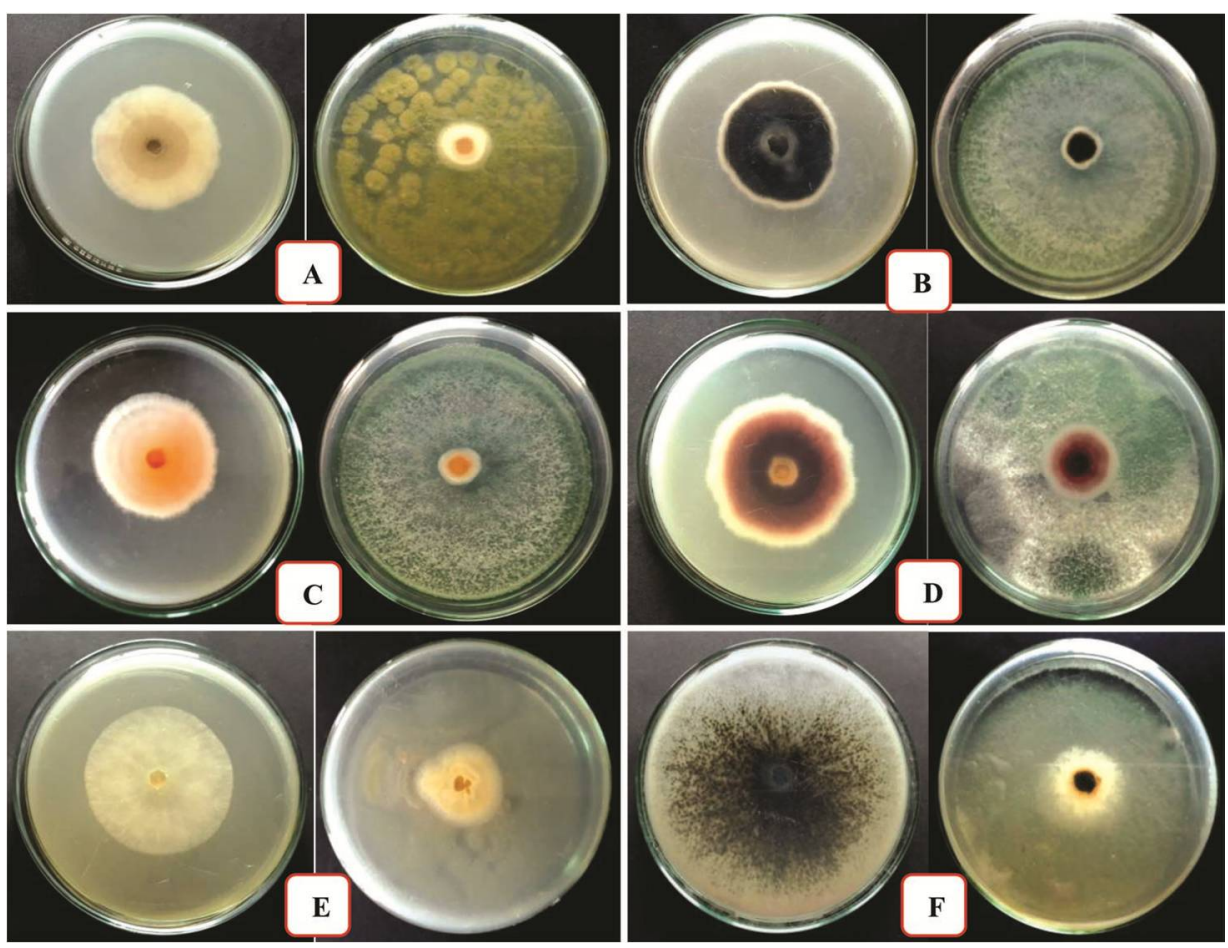

Fig. 2. Growth inhibition of pathogenic fungi owing to volatile metabolites of the antagonists. A. A. flavus: Colletotrichum gloeosporioides; B. T. viride: Curvularia lunata; C. T. viride: Fusarium nivale; D. T. viride: Fusarium moniliforme; E. A. fumigatus: Mucor sp. and F. A. fumigatus: Rhizoctonia solani.

Table 3 shows the effect of non-volatile metabolites on the growth of $C$. gloeosporioides, $C$. lunata, F. nivale, F. moniliforme, Mucor sp. and $R$. solani. The maximum inhibition of radial growth of $C$. gloeosporioides was observed with the culture filtrates of $A$. niger (76.3\%), which was followed by $T$. viride (70.9\%), A. fumigatus (58.4\%) and A. flavus $(57.7 \%)$ at $20 \%$ concentration. The maximum inhibition of radial growth of Curvularia lunata was observed with the culture filtrates of Trichoderma viride (78.2\%) which was followed by A. niger (73.1\%), A. flavus (72.3\%), and A. fumigatus $(57.4 \%)$ at $20 \%$ concentration. The highest inhibition of radial growth of Fusarium moniliforme was 
observed with the culture filtrates of $T$. viride (76.3\%), which was followed by A. niger (74.0\%), A. fumigatus $(67.2 \%)$ and A. flavus $(56.3 \%)$ at $20 \%$ concentration.

Table 3. Percent inhibition of radial growth of test pathogens by non-volatile metabolites of antagonistic fungi.

\begin{tabular}{|c|c|c|c|c|c|c|}
\hline \multirow[t]{2}{*}{ Test pathogens } & \multirow{2}{*}{$\begin{array}{l}\text { Concen- } \\
\text { tration } \\
(\%)\end{array}$} & \multicolumn{4}{|c|}{$\begin{array}{c}\text { \% inhibition of radial growth of test pathogens by } \\
\text { non-volatile metabolites owing to different } \\
\text { antagonists }\end{array}$} & \multirow[t]{2}{*}{$\begin{array}{l}\mathrm{CV} \\
(\%)\end{array}$} \\
\hline & & $\begin{array}{c}\text { Aspergillus } \\
\text { flavus }\end{array}$ & $\begin{array}{c}A . \\
\text { fumigatus }\end{array}$ & $\begin{array}{c}\text { A. } \\
\text { niger }\end{array}$ & $\begin{array}{c}\text { Trichoderma } \\
\text { viride }\end{array}$ & \\
\hline \multirow{4}{*}{$\begin{array}{l}\text { Colletotrichum } \\
\text { gloeosporioides }\end{array}$} & 5 & $28.9^{c}$ & $27.6^{\mathrm{d}}$ & $47.2^{\mathrm{a}}$ & $41.8^{\mathrm{b}}$ & 0.0275 \\
\hline & 10 & $48.8^{c}$ & $42.5^{\mathrm{d}}$ & $58.1^{\mathrm{a}}$ & $49.0^{\mathrm{b}}$ & 0.0201 \\
\hline & 15 & $55.5^{\mathrm{c}}$ & $51.0^{\mathrm{d}}$ & $66.0^{\mathrm{a}}$ & $65.4^{\mathrm{b}}$ & 0.0168 \\
\hline & 20 & $57.7^{\mathrm{d}}$ & $58.4^{\mathrm{c}}$ & $76.3^{\mathrm{a}}$ & $70.9^{b}$ & 0.0152 \\
\hline \multirow[t]{4}{*}{ Curvularia lunata } & 5 & $36.1^{\mathrm{d}}$ & $38.1^{\mathrm{c}}$ & $56.3^{\mathrm{a}}$ & $45.6^{\mathrm{b}}$ & 0.0227 \\
\hline & 10 & $48.9^{c}$ & $44.6^{\mathrm{d}}$ & $65.4^{\mathrm{a}}$ & $65.2^{\mathrm{b}}$ & 0.0178 \\
\hline & 15 & $63.8^{c}$ & $53.1^{\mathrm{d}}$ & $72.7^{\mathrm{a}}$ & $69.5^{\mathrm{b}}$ & 0.0154 \\
\hline & 20 & $72.3^{c}$ & $57.4^{\mathrm{c}}$ & $73.1^{\mathrm{b}}$ & $78.2^{\mathrm{a}}$ & 0.0142 \\
\hline Fusarium & 5 & $30.9^{\mathrm{d}}$ & $38.1^{\mathrm{b}}$ & $33.3^{\mathrm{c}}$ & $43.6^{\mathrm{a}}$ & 0.0685 \\
\hline \multirow[t]{3}{*}{ moniliforme } & 10 & $43.6^{\mathrm{d}}$ & $52.7^{\mathrm{c}}$ & $55.5^{\mathrm{a}}$ & $54.5^{\mathrm{b}}$ & 0.0224 \\
\hline & 15 & $50.9^{\mathrm{d}}$ & $58.1^{\mathrm{c}}$ & $62.9^{\mathrm{b}}$ & $65.4^{\mathrm{a}}$ & 0.0168 \\
\hline & 20 & $56.3^{\mathrm{d}}$ & $67.2^{\mathrm{c}}$ & $74.0^{\mathrm{b}}$ & $76.3^{\mathrm{a}}$ & 0.0146 \\
\hline \multirow[t]{4}{*}{ Fusarium nivale } & 5 & $33.3^{\mathrm{b}}$ & $30.9^{\mathrm{d}}$ & $32.7^{\mathrm{c}}$ & $50.0^{\mathrm{a}}$ & 0.0272 \\
\hline & 10 & $40.4^{\mathrm{c}}$ & $38.1^{\mathrm{d}}$ & $50.9^{\mathrm{b}}$ & $64.0^{\mathrm{a}}$ & 0.0207 \\
\hline & 15 & $47.6^{\mathrm{d}}$ & $50.0^{\mathrm{c}}$ & $67.2^{\mathrm{b}}$ & $68.1^{\mathrm{a}}$ & 0.0871 \\
\hline & 20 & $64.2^{\mathrm{d}}$ & $71.4^{\mathrm{c}}$ & $81.8^{\mathrm{a}}$ & $74.0^{\mathrm{b}}$ & 0.0137 \\
\hline \multirow[t]{4}{*}{ Mucor sp. } & 5 & $27.5^{\mathrm{d}}$ & $36.4^{\mathrm{b}}$ & $35.0^{\mathrm{c}}$ & $38.6^{\mathrm{a}}$ & 0.0290 \\
\hline & 10 & $38.8^{\mathrm{d}}$ & $44.7^{\mathrm{a}}$ & $43.7^{\mathrm{c}}$ & $44.0^{\mathrm{b}}$ & 0.0234 \\
\hline & 15 & $42.3^{\mathrm{d}}$ & $55.3^{\mathrm{a}}$ & $53.7^{\mathrm{c}}$ & $54.6^{\mathrm{b}}$ & 0.0194 \\
\hline & 20 & $47.0^{\mathrm{d}}$ & $64.7^{\mathrm{a}}$ & $57.5^{\mathrm{c}}$ & $60.0^{\mathrm{b}}$ & 0.0581 \\
\hline \multirow[t]{4}{*}{ Rhizoctonia solani } & 5 & $20.0^{\mathrm{a}}$ & $10.0^{\mathrm{d}}$ & $18.8^{\mathrm{b}}$ & $14.1^{\mathrm{c}}$ & 0.0634 \\
\hline & 10 & $37.7^{b}$ & $22.2 \mathrm{~d}$ & $31.1^{\mathrm{c}}$ & $54.1^{\mathrm{a}}$ & 0.0275 \\
\hline & 15 & $45.5^{\mathrm{b}}$ & $30.0^{\mathrm{d}}$ & $37.7^{\mathrm{c}}$ & $58.8^{\mathrm{a}}$ & 0.0232 \\
\hline & 20 & $55.5^{\mathrm{d}}$ & $72.2^{\mathrm{c}}$ & $58.8^{\mathrm{b}}$ & $62.8^{\mathrm{a}}$ & 0.0211 \\
\hline
\end{tabular}

Means followed by the same letter within a column did not differ significantly at $5 \%$ level by DMRT.

The highest inhibition of radial growth of $F$. nivale was observed with the culture filtrates of A. niger (81.8\%), which was followed by T. viride (74.0\%), A. fumigatus (71.4\%) and A. flavus (64.2\%) at $20 \%$ concentration. The maximum inhibition of radial growth of Mucor sp. was observed with the culture filtrates of A. fumigatus (64.7\%) 
which was followed by $T$. viride (60.0\%), A. niger (57.5\%) and A. flavus $(47.0 \%)$ at $20 \%$ concentration. The maximum inhibition of radial growth of Rhizoctonia solani was observed with the culture filtrates of A. fumigatus $(72.2 \%)$, which was followed by $T$. viride (62.8\%), A. niger (58.8\%) and A. flavus (55.5\%) at 20\% concentration (Table 3). Differences in percent inhibition with the present study might be due to the differences in organism strains involved in the interaction (Table 3 and Fig. 3).
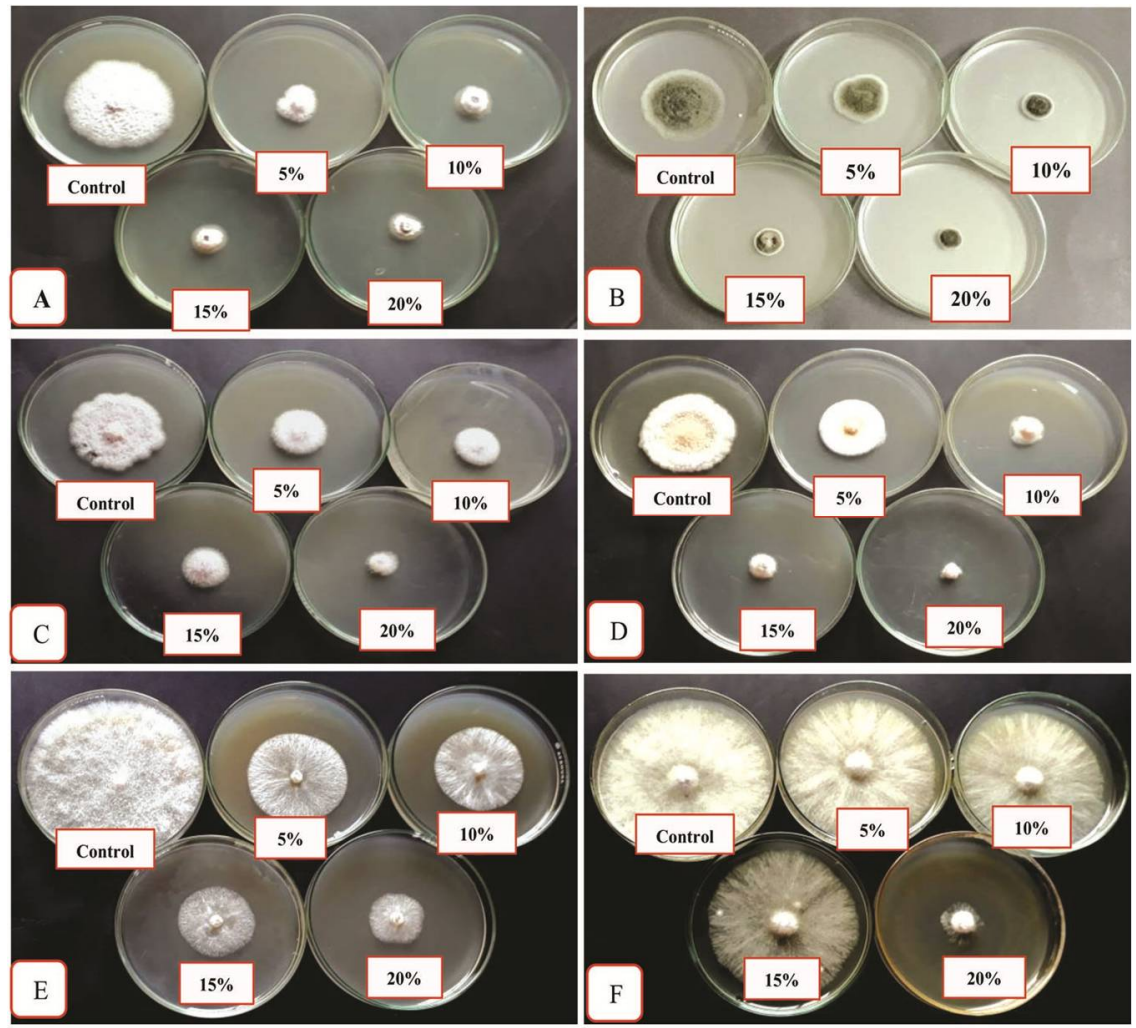

Fig. 3. Growth inhibition of pathogenic fungi owing to non-volatile metabolites of antagonists at 5, 10, 15 and $20 \%$ concentrations. A. Colletotrichum gloeosporioides: Aspergillus niger; B. Curvularia lunata: Trichoderma viride; C. Fusarium moniliforme: T. viride; D. Fusarium nivale: A. niger; E. Mucor sp.: Aspergillus fumigatus and F. Rhizoctonia solani: A. fumigatus.

Similar result was found in the research of of Akter et al. 2014, Bashar and Chakma 2014, Helal and Shamsi 2019, where A. flavus, A. fumigatus, A. niger and T. viride showed significant growth inhibition against Colletotrichum spp., Curvularia lunata and Fusarium spp. 
The non-volatile metabolites produced from the culture filtrates of $T$. viride and A. niger were responsible for maximum inhibition against different pathogenic species of Colletotrichum and Fusarium according to Al-Ameen et al. 2017 and Madhanraj et al. 2010.

Tapwal et al. (2015) also reported that, culture filtrates of $T$. viride showed major growth inhibition on $C$. gloeosporioides. A number of Trichoderma species are effective agents for the control of plant pathogenic fungi, such as Fusarium spp. (Sivan and Chet 1986), Pythium spp. (Naseby et al. 2000) and Rhizoctonia spp. (Lewis and Papavizas 1987).

The present investigation suggests that the isolates of Aspergillus and Trichoderma may be further exploited as potential biocontrol agents against the fungal pathogens of cotton in field trial.

\section{Acknowledgements}

The first author gratefully acknowledges to the "Ministry of Science and Technology", People's Republic of Bangladesh for providing financial support in her research through NST fellowship.

\section{References}

Aktar, M.T., K.S. Hossain and M.A. Bashar. 2014. Antagonistic potential of rhizosphere fungi against leaf spots and fruit rot pathogens of brinjal. Bangladesh J. Bot. 43(2): 213-217.

Al-Ameen, M., S. Shamsi, S. Hosen and M.A. Bashar. 2017. Antagonistic potential of soil fungi against post-harvest pathogenic fungi of Musa sapientum L. Bangladesh J. Bot. 46(2): 733738.

Amer O.E., M.A. Mahmoud, A. El-Rahim and El-Samawaty. 2011. Nonliquid nitrogen-basedmethodfor isolation of DNA from filamentous fungi. Afr. J. Biotechnol. 10(65):14337-14341.

Barnett, H.L. and S.B. Hunter. 1972. Illustrated Genera of Imperfect Fungi. Burgess Publishing Company, Minneapolis. Third Edition, pp. 44-45.

Bashar, M.A. and M. Chakma. 2014. In vitro control of Fusarium solani and F. oxysporum the causative agent of brinjal wilt. Dhaka Univ. J. Biol. Sci. 23(1): 53-60.

Bashar, M.A. and B. Rai. 1994. Antagonistic potential of root-region microflora of chickpea against Fusarium oxysporum f. sp. ciceri. Bangladesh J. Bot. 23(1): 13-19.

Benoit, M.A. and S.B. Mathur. 1970. Identification of species Curvularia on rice seed. Proc. Inst. Seed Test. Ass. 35(1): 1-23.

Booth, C. 1971. The Genus Fusarium. The Commonwealth Mycological Institute, Kew, England. pp. 267.

CAB (Commonwealth Agricultural Bureau). 1968. Plant Pathologist Pocket Book. 1st edn. The Commonwealth Mycological Institute, Kew. pp. 267.

Ellis, M.B. 1971. Dematiaceous Hyphomycetes. $1^{\text {st }}$ edn. The Commonwealth Mycological Institute, Kew, Surrey, England. pp. 608. 
Ellis, M.B. 1976. More Dematiaceous Hyphomycetes. The Commonwealth Mycological Institute, Kew. pp. 507.

Fokkema, N.J. 1976. Antagonism between fungal saprophytes and pathogens on aerial plant surfaces. In: Microbiology of Aerial Plant Surfaces (eds. Dickinson CH and TF Preece), Academic Press, London, pp. 487-505.

Goswami, D. and M. Islam. 2002. In vitro study of antagonism of Trichoderma sp. and Bacillus subtilis against Fusarium oxysporum f.sp. lycopersici (Sacc.). J. Agril. Sci. Society of North-E a s t India. 17: 24-26.

Helal, R.B. and S. Shamsi. 2019. Antagonistic potentials of some soil fungi against three postharvest pathogenic fungi of Carica papaya L. Dhaka Univ. J. Biol. Sci. 28(1): 1-7.

ISTA. 1996. International Rules of Seed Testing Association. In. Proc. Int. Seed Test. Assoc. pp. $19-41$.

Lewis, J. A. and G.C. Papavizas. 1987. Application of Trichoderma and Gliocladium in alginate pellets for control of Rhizoctonia damping-off. Plant Pathol. 36: 438-446.

Madhanraj, P., V. Ambikapathy and A. Panneerselvam. 2010. Biological control of banana wilt caused by Fusarium solani (Mart.) Sacc. Int. J. Appl. Biol. Pharm. Technol. 1(3): 1032-1039.

Minton, E.B. and Garber. 1983. Controlling the seedling disease complex of cotton. Plant Dis., 67:115-118.

Munro, J.M. 1994. Cotton and its production, insect pests of cotton, CAB International, Wallingford. pp. 47-52.

Naznin, S. and S. Shamsi. 2018. Pathogenic potentiality of fungi isolated from seeds of three hill cotton varieties (Gossypium arboreum L.). Dhaka Univ. J. Biol. Sci. 28(2): 187-193.

Naseby, D.C., J.A. Pascual and J.M. Lynch. 2000. Effect of biocontrol strains of Trichoderma on plant growth, Pythium ultimum populations, soil microbial communities and soil enzyme activities. J. Appl. Microbiol. 88: 161-169.

Patel, K.D. and K.R. Joshi. 2001. Antogonistic effect of some bioagents in vitro against Colletotrichum gloeosporioides Penz. and Sacc. The causal agent of leaf spot of turmeric. $J$. Mycol. Plant Path. 31: 126.

Raper, K. B. and C. Thom. 1949. A Manual of the Penicillia. Williams and Wilkins, Baltimore, MD. pp. 875.

Sivan, A. and I. Chet. 1986. Biological control of Fusarium spp. in cotton, wheat and muskmelon by Trichoderma harzianum. J. Phytopathol. 116: 39-47.

Skidmore A.M. and Dickinson C.H. 1976. Colony interaction and hyphal interference between Septoria nodorum and phylloplane fungi. Trans. Brit. Mycol. Soc. 66: 57-64.

Subramanian, C.V. 1971. Hyphomycetes. Indian Council of Agriculture Research, New Delhi. pp. 930.

Sunitha, J. Waghmare and B.P. Kurundkar. 2007. Efficacy of local isolates of Trichoderma spp. against Fusarium oxysporum f. sp. ciceri. J. Plant Dis. Sci. 2(1): 48-50.

Sutton, B.C. 1980. The Coelomycetes, Common Wealth Mycological Institute, Kew Surrey, England, pp. 1-696.

Tapwal, A., A. Tyagi, G. Thakur and S. Chandra. 2015. In vitro evaluation of Trichoderma species against seed borne pathogens. IJCBS Research Paper 1(10).

Thom, C. and K.B. Raper. 1945. A Manual of the Aspergilli. Williams and Wilkins, Baltimore, MD. pp. 373. 